\title{
USABILITY TESTING SISTEM PADA E-ACADEMIC POLITEKNIK HARAPAN BERSAMA
}

\author{
Dega Surono Wibowo** \\ Jurusan Teknik Informatika, Politeknik Harapan Bersama Tegal \\ (cooresponding author)dega.wibowo@gmail.com ${ }^{*}$
}

\begin{abstract}
Web-based public services, it has become a very important part in supporting the success of an educational institution, but web-based services are still many difficulties in using it, even unattractive and does not function as it should. The reason web pages need to be measured to determine the quality of the web site from the user side. Does the web page in accordance with the standardization issued by the Ministry of Communications of the Republic of Indonesia in 2003. This measurement can use usablility method of testing or usability testing. According to Jacob Nielson (2003), Testing Usability (Usability Testing) has five basic components are studied (learnability), efficient (efficiency), memorable (memorability), safe to use and reduce the error rate (erross) and have high levels of satisfaction (satisfaction).
\end{abstract}

\section{Keyword-Measure, Usability Testing, Website.}

Intisari-Layanan publik yang berbasiskan web saat ini sudah menjadi bagian yang sangat penting dalam menunjang keberhasilan dari suatu instansi pendidikan, akan tetapi layanan yang berbasiskan web masih banyak yang kesulitan dalam menggunakannya, bahkan tidak menarik dan tidak berfungsi sebagai mana mestinya. Alasan laman web perlu diukur adalah untuk mengetahui kualitas situs web tersebut dari sisi pengguna. Apakah laman web tersebut sesuai dengan standarisasi yang dikeluarkan oleh Kementrian Komunikasi Republik Indonesia tahun 2003. Pengukuran ini bisa menggunakan metode usablility testing atau uji kebergunaan. Menurut Jacob Nielson (2003), Pengujian Kebergunaan (Usability Testing) memiliki lima komponen dasar yaitu dipelajari (learnability), efisien (efficiency), mudah diingat (memorability), aman untuk digunakan dan mengurangi tingkat kesalahan (error) dan memiliki tingkat kepuasan (satisfaction).

\section{Kata Kunci-Mengukur, Usability Testing, Website}

\section{PENDAHULUAN}

Institusi pendidikan tinggi merupakan lembaga utama yang menciptakan para calon praktisi di dalam dunia industri, salah satu program pendidikan yang turut berperan aktif dalam menciptakan praktisi adalah pendidikan dengan jalur vokasi. Pendidikan vokasi merupakan pendidikan tinggi yang diarahkan terhadap penguasaan keahlian terapan tertentu. Politeknik Harapan Bersama merupakan salah satu lembaga pendidikan tinggi yang berjalan di jalur vokasi yang menyediakan Sumber Daya Manusia (SDM) untuk menjadi tenaga ahli di dalam suatu perusahaan atau industry. Politeknik Harapan Bersama merupakan salah satu perguruan tinggi swasta yang menyelenggarakan pendidikan di jalur vokasi di Kota Tegal. Pada tahun 2015 institusi ini telah memiliki 7 program studi, di antaranya D4 Teknik Informatika, D3 Kebidanan, D3 Farmasi, D3 Teknik Komputer, D3 Akuntansi, D3 Teknik Mesin dan D3 Teknik Elektronika.

Dalam menunjang proses pendidikan vokasi, Politeknik Harapan Bersama menyediakan beberapa sarana dan prasarana, di antaranya: ruang kelas yang representative, perpustakaan yang nyaman, rumah susun mahasiswa, laboratorium di tiap-tiap program studi, hotspot area, sms gateway, web informasi institusi dan sebagainya. Dengan fasilitas yang cukup lengkap, sudah semestinya Politeknik Harapan Bersama memiliki informasi akademik yang 
menunjang pada setiap program studinya. Namun demikian informasi yang disampaikan di setiap program studi masih menggunakan metode-metode yang tidak efisien, salah satunya terdapat pada program studi D4 Teknik Informatika.

Dalam tata cara penyampaian informasi akademik Program Studi D4 Teknik Informatika masih menggunakan cara yang tidak maksimal, seperti: (1) Penyampaian informasi profil program studi hanya menggunakan pamflet dan brosur; (2) Penyampaian informasi akademik masih mengandalkan surat edaran yang dibagikan ke setiap mahasiswa atau ditempelkan pada papan pengumuman; (3) Informasi perkuliahan masih mengandalkan pemanfaatan sms gateway. Berdasarkan fasilitas yang telah disediakan oleh institusi, sudah semestinya program studi D4 Teknik Informatika mempunyai media penyampaian informasi akademik elektronik secara online dan realtime yang diharapkan dapat diintegrasikan dengan media web yang telah dimiliki oleh institusi, sehingga penyampaian informasi akademik dapat berjalan lebih efektif dan efisien.

Layanan publik seperti e-akademic yang dimiliki oleh D4 Teknik Informatika sudah menjadi bagian yang sangat penting sehingga perlu diukur untuk mengetahui kualitas dari $e$ akademic itu sendiri. Pengukuran ini bias menggunakan metode usability testing atau uji ketergunaan. Menurut Jacob Nielson [1] pengujian ketergunaan (usability testing) memiliki 5 komponen utama yaitu learnabiliy, efficiency, memorability, errors dan satisfaction.

\section{METODOLOGI PENELITIAN}

Tahap-tahap yang dilakukan dalam penelitian usability testing di antaranya menentukan evaluator, melakukan survei dengan kuisioner, melakukan pemilihan fungsi, membuat tugas usability, menyusun skrip usability test, melaksanakan usability test dengan cara melakukan wawancara, melakukan analisis data dari hasil usability test dan survei, menyusun rekomendasi perbaikan aplikasi, di mana proses pengumpulan data dengan cara melakukan observasi secara langsung.

Tahap berikutnya adalah melakukan wawancara, dengan cara memberikan pertanyaan-pertanyaan yang telah dirangkum dalam suatu kuisioner yang akan di isi oleh responden yang akan menilai sistem $e$-academic. Tahap penelitian selanjutnya adalah sebagai berikut :

\section{1) Menentukan Evaluator}

Evaluator terhadap pengujian usability menurut Rusidi ( 200 ) [4] adalah untuk mengukur penggunaan e-academic D4 Teknik Informatika, yaitu pengguna Awam, Pengguna Aktif dan Pengguna Terampil. Pengguna awan merupakan pengguna yang baru sekali menggunakan e-academic ini, pengguna aktif biasanya merupakan pengguna yang sudah sering menggunakan e-acedemic ini, sedangkan untuk pengguna terampil merupakan pengguna yang sudah mahir dalam menggunakan e-acedemic ini.

\section{2) Melakukan Survei dengan Kuisioner}

Pemilihan dari responder ini berdasarkan pada isian pertanyaan dan identitas responden, responden dibagi menjadi 3 level pengguna. Yaitu pengguna awam biasanya terdiri dari mahasiswa, untuk pengguna aktif biasanya karyawan/pegawai, sedangkan pengguna terampil biasanya adalah staff IT.

TABEL I

RESPONDEN

\begin{tabular}{c|l|l|l}
\hline Responden & Pekerjaan & Umur & $\begin{array}{c}\text { Jenis } \\
\text { Kelamin }\end{array}$ \\
\hline 1 & Mahasiswa & 20 Tahun & Laki-Laki \\
2 & Pegawai & 22 Tahun & Perempuan \\
3 & Staff IT & 26 Tahun & Laki-Laki \\
\hline
\end{tabular}

3) Membuat Tugas Usablility Test

Dalam membuat tugas usability testing yang akan ditanyakan terhadap responden 
yang telah dipilih adalah berdasarkan learnability, effisiency, memorability, errors dan satisfaction. Setiap komponen tersebut akan dibuat skrip agar tugas yang dibuat tidak akan lebih dari 60 menit.

TABEL III

RESPONDEN

\begin{tabular}{lll}
\hline Responden & Pekerjaan & $\begin{array}{c}\text { Waktu } \\
\text { Pengujian }\end{array}$ \\
\hline 1 & Mahasiswa & 60 Menit \\
2 & Pegawai & 60 Menit \\
3 & Staff IT & 60 Menit \\
\hline
\end{tabular}

4) Menyusun Skrip Usablility Test

Membuat usability testing yang akan ditanyakan kepada responden yang telah dipilih, kemudian kuisoner akan dibagikan kepada responden untuk memberikan nilai sebagai bahan acuan dalam membuat skrip usability test. Skrip usability test ini menggunakan usability test script dari Steve Krug [2].

5) Melaksanakan Usability Test dengan Melakukan Wawancara

Rekapitulasi jawaban dari responden berdasarkan kuisoner yang disebarkan kepada 3 macam responden, baik responden awam, responden aktif dan responden terampil, untuk melakukan pengujian terhadap e-academic D4 Teknik Informatika.

\section{HASIL DAN PEMBAHASAN}

Kualitas website menurut adalah seberapa baik sebuah halaman web yang dirancang dan seberapa baik desain bertemu dengan kepuasan dari pengguna. Hasil dari usability testing untuk mengukur tingkat penggunaan e-academic D4 Teknik Informatika yang dibangun dengan bahasa PHP. Tampilan dari e-academic D4 Teknik Informatika yang beralamat http://informatika.poltektegal.ac.id seperti di bawah ini.

\section{A. Tampilan Interface e-Academic Yang Diuji 1) Halaman Home}

Halaman Home merupakan halaman pertama ketika e-academic D4 Teknik Informatika ditampilkan, tampilannya seperti gambar di bawah ini.

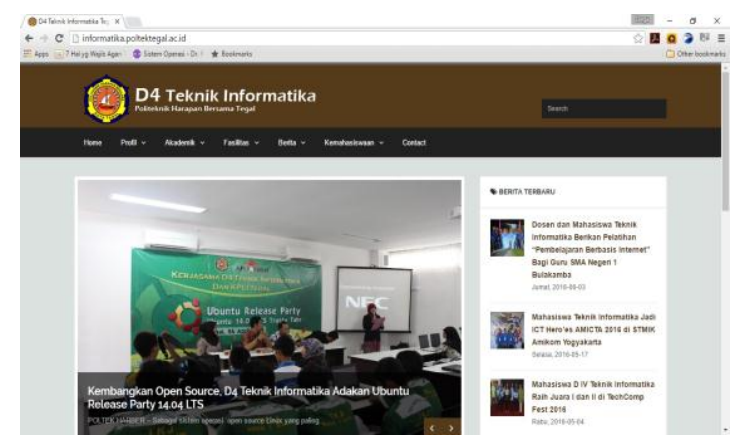

Gambar 1. Halaman Home

\section{2) Halaman Profil}

Halaman profil berisi menu tentang Sejarah, Visi Misi dan Tujuan, Struktur Organisasi, Dosen Tetap, Penelitian, Pengabdian, Kerja Sama, berikut merupakan tampilan dari salah satu menu di dalam halaman profil, yaitu menu Visi Misi dan Tujuan, tampilannya seperti gambar di bawah ini.

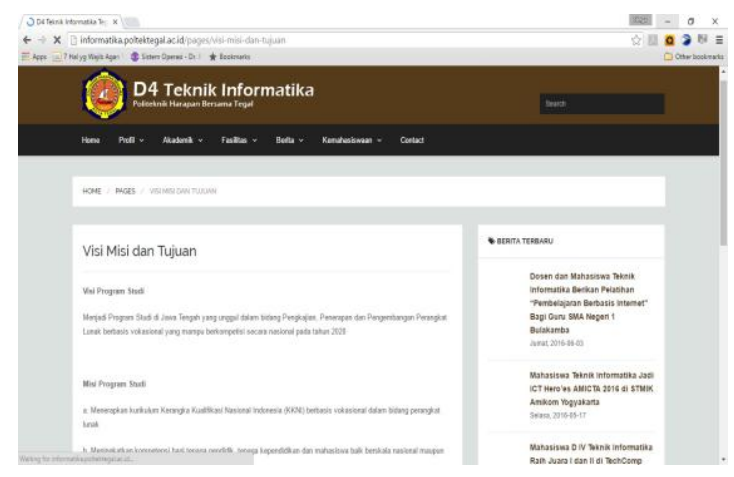

Gambar 2. Halaman Visi Misi dan Tujuan

\section{3) Halaman Akademik}

Halaman Akademik berisi menu tentang pedoman akademik, pedoman KP, pedoman KKL, Pedoman TA, Kalender Akademik, Kurikulum, Jadwal Kuliah, berikut merupakan tampilan dari salah satu menu di dalam Akademik, yaitu Menu Pedoman Akademik, Tampilannya seperti gambar di bawah ini: 


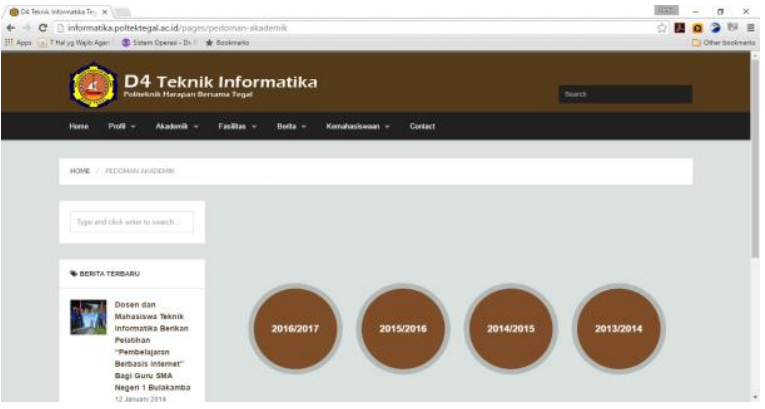

Gambar 3. Halaman Pedoman Akademik

\section{6) Hasil Analisa Data Hasil Usability Test dan Survei}

Menghitung persentase pada perintah dalam "Formulir Uji Ketergunaan".

Perhitungan ini dilakukan dengan merubah ke dalam bentuk angka "1 (satu)" apabila jawaban "bisa ditemukan" atau tanda centang "N" dan angka "0 (nol) diberikan terhadap jawaban "tidak bisa ditemukan".

Dari setiap poin perintah akan dihitung persentasenya, sehingga akan diketahui berapa persen yang ditemukan dan berapa persen yang tidak ditemukan. Dari setiap poin perintah di setiap sub bagian akan dihitung sub total dari nilai persentasenya dan yang terakhir adalah menghitung total persentase dari keseluruhan jawaban yang diberikan kepada responden, baik dari jawaban yang bisa dijawab maupun jawaban yang tidak bisa dijawab.

TABEL IIIII

PERSENTASE JAWABAN RESPONDEN

\begin{tabular}{|c|c|c|c|c|c|c|}
\hline \multirow[t]{2}{*}{ No } & \multirow[t]{2}{*}{ Pertanyan } & \multicolumn{3}{|c|}{$\begin{array}{l}\text { Responden } \\
\text { (dalam } \\
\text { angka) } \\
\end{array}$} & \multirow[t]{2}{*}{$\begin{array}{c}\text { Ditemukan } \\
(\%)\end{array}$} & \multirow[t]{2}{*}{$\begin{array}{l}\text { Tidak } \\
\text { ditemukan } \\
\quad(\%)\end{array}$} \\
\hline & & R1 & R2 & R3 & & \\
\hline \multicolumn{7}{|c|}{ Learnability } \\
\hline 1 & $\begin{array}{l}\text { Apakah tulisan teks yang digunakan untuk } \\
\text { halaman tersebut mudah dan jelas bagi } \\
\text { anda, mengapa? }\end{array}$ & 1 & 1 & 1 & 100 & 0 \\
\hline 2 & $\begin{array}{l}\text { Apakah menu-menu yang ada pada sistem } \\
\text { dapat dengan mudah dipahami ? uraikan }\end{array}$ & 1 & 1 & 1 & 100 & 0 \\
\hline 3 & $\begin{array}{l}\text { Apakah anda menemukan menu untuk } \\
\text { mengunduh pada halaman ini ? adakah } \\
\text { menu searching pada halaman ini ? }\end{array}$ & 1 & 1 & 1 & 100 & 0 \\
\hline Tota & & & & & 100 & 0 \\
\hline \multicolumn{7}{|c|}{ Efficiency } \\
\hline 4 & $\begin{array}{l}\text { Saat menu-menu tersebut anda klik, } \\
\text { apakah dapat tampil dengan cepat? } \\
\text { Uraikan }\end{array}$ & 1 & 1 & 1 & 100 & 0 \\
\hline 5 & $\begin{array}{l}\text { Apakah judul dapat langsung ditampilkan, } \\
\text { ketika anda mengetik pada mesin } \\
\text { pencarian? }\end{array}$ & 1 & 0 & 0 & 33,33 & 66,66 \\
\hline 6 & $\begin{array}{l}\text { Saat anda akan mengunduh apakah } \\
\text { diberikan informasi tentang format file dan } \\
\text { ukurannya? }\end{array}$ & 1 & 1 & 0 & 66,66 & 33,33 \\
\hline \multicolumn{2}{|r|}{ Total } & & & & 66,66 & 33,33 \\
\hline
\end{tabular}


7 Apakah nama halaman web yang sedang anda kunjungi, tuliskan nama alamatnya?

8 Apakah alamat tersebut penulisannya menggunakan huruf kecil?

Apakah alamat web tersebut mengandung underline?

10 Apakah halaman ini menggunakan gambar animasi? Uraikan

$\begin{array}{ccccc}1 & 1 & 1 & 100 & 0 \\ 1 & 1 & 1 & 100 & 0 \\ 0 & 0 & 0 & 0 & 100 \\ 0 & 1 & 0 & 33,33 & 66,66 \\ & & & 58,33 & 41,66\end{array}$

Total

Error

Apakah anda menemukan link yang anda

11 klik mengalami error? Tuliskan link tersebut

12 Apakah ada pesan yang jelas, saat link tersebut error? Uraikan

1

Apakah anda menemukan tidak adanya

13 respon ketika menu-menu di web anda

klik?

Apakah anda menemukan peringatan

under reconstruction dari beberapa menu

atau link yang ditampilkan dalam halaman

$\begin{array}{llll}1 & 1 & 1 & 100\end{array}$

0 ini?

Total

Satisfaction

15 Apakah anda ingin mengunjungi halaman

ini kembali? Jika iya apa yang anda cari

$\begin{array}{lllll}1 & 1 & 1 & 100 & 0\end{array}$

Apakah yang anda dapatkan ketika

16 berkunjung ke halaman ini?

17 Apakah informasi yang ditampilkan up to date?

Dapatkan anda menemukan kelengkapan

18 lain yang mendukung seperti file share, chat, milis dan lain-lain?

Tuliskan menu yang anda butuhkan yang

19 belum terdapat pada web ini tetapi anda pernah temui pada web lain yang pernah anda kunjungi?

Total

$\begin{array}{lllll}1 & 1 & 1 & 100 & 0\end{array}$

0

Total Keseluruhan

TABEL IVV

KUANTITATIF

\begin{tabular}{ccc}
\hline Skor & Kualifikasi & Hasil \\
\hline $85 \%-100 \%$ & Sangat Baik (SB) & Berhasil \\
$65 \%-84 \%$ & Baik (B) & Berhasil \\
$55 \%-64 \%$ & Cukup (C) & Tidak Berhasil \\
$0 \%-54 \%$ & Kurang (K) & Tidak Berhasil \\
\hline
\end{tabular}


Dari perhitungan persentase jawaban responden pada usability testing yang dilakukan untuk mengukur website $e$ akademic D4 Teknik Informatika dapat disimpulkan bahwa 75,67 \% pertanyaan mampu dijawab oleh responden (jawaban dapat ditemukan), sedangkan 24,33\% pertanyaan tidak dapat dijawab oleh responden (jawaban tidak ditemukan).

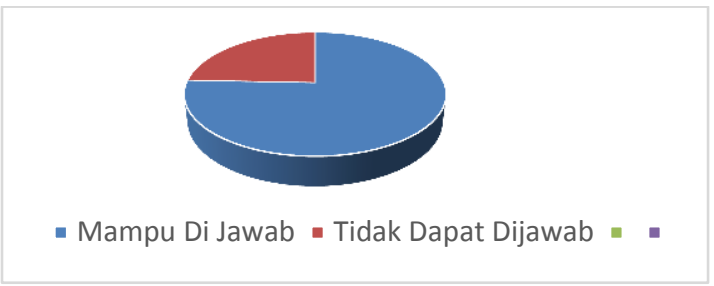

Gambar 4. Grafik Perhitungan Persentase Responden

Menurut Arikunto [4], tabel kuantitatif untuk hasil perhitungan terhadap kuisoner pada usability testing untuk mengukur penggunaan website e-academic D4 Teknik Informatika.

Dengan perhitungan sebagai berikut :

7) Menyusun Rekomendasi Perbaikan Aplikasi

Berdasarkan analisa yang didapatkan, maka dibuat suatu rekomendasi yang tidak ditemukan dalam perbaikan aplikasi yang telah dinilai dari 3 responden dengan tingkat level yang berbeda, terutama dari aspek usabilitinya.

B. Hasil Penelitian

Dari beberapa tugas atau pertanyaan yang diberikan kepada responden hasilnya terbagi menjadi dua yaitu :

1) Berhasil ditemukan

Untuk proses kemudahan dipelajari (learnability) diperoleh angka $100 \%$, efisien (efficiency) diperoleh angka $66,66 \%$, kemudahan diingat (memerability) memperoleh angka $58,33 \%$, untuk tingkat kesalahan (error) diperoleh angka $100 \%$, dan tingkat kepuasan (Satisfaction) memperoleh angka 53,33\%

2) Tidak berhasil ditemukan

Sedangkan untuk semua task yang tidak dapat diselesaikan oleh responden adalah sebagai berikut, untuk proses kemudahan dipelajari (learnability) dan kemudahan untuk diingat (memorability) memperoleh angkat 58,33 \%, untuk tingkat kesalahan (error) diperoleh angka $100 \%$, dan tingkat kepuasan (Satisfaction) memperoleh angka persentase untuk seluruh pertanyaan yang dapat dikerjakan dari setiap aspek 75,67 \% dan pertanyaan yang tidak dapat diselesaikan responden adalah $24,33 \%$

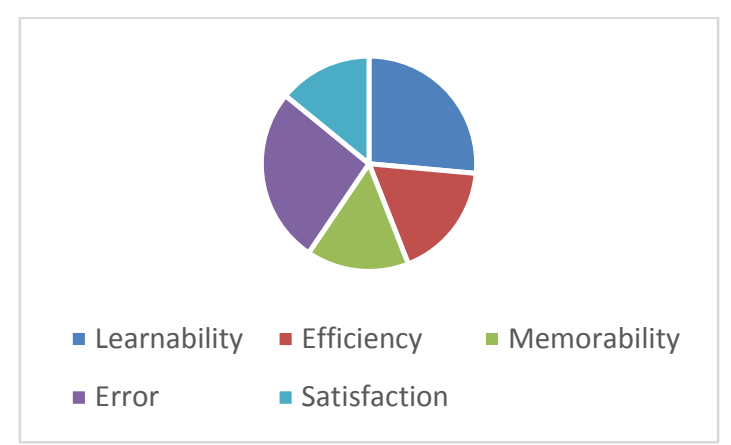

Gambar 5. Grafik Hasil Penelitian Berhasil Ditemukan

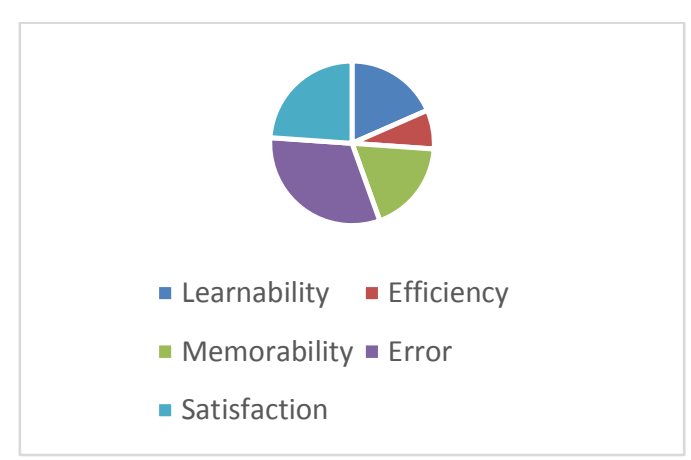

Gambar 6 Grafik Hasil Penelitian Tidak Berhasil Ditemukan 


\section{KESIMPULAN}

Dalam penelitian yang dilakukan ini diperoleh hasil persentase usability testing untuk mengukur penggunaan website e-academic $\mathrm{D} 4$ Teknik Informatika. Learnability sebesar $100 \%$ pertanyaan mampu dijawab, $0 \%$ pertanyaan tidak dapat dijawab oleh responden, efficiency yang didapat dari penelitian ini sebesar $66,66 \%$ pertanyaan yang mampu dijawab oleh responden dan $33,33 \%$ pertanyaan tidak mampu dijawab oleh responden, untuk memorability mendapatkan 58,33 \% untuk pertanyaan yang mampu dijawab oleh responden dan 41,66\% pertanyaan tidak mampu dijawab oleh responden, untuk kriteria error sebesar $100 \%$ pertanyaan mampu di jawab oleh responden, dan $0 \%$ pertanyaan tidak bisa di jawab oleh responden, satisfaction memperoleh 53,33 \% pertanyaannya mampu dijawab oleh responden, dan 46,66 \% responden tidak dapat menjawab pertanyaan.

Pada penelitian yang dilakukan keseluruhan jawaban responden adalah sebesar 75,67 \% pertanyaan yang mampu dijawab oleh para responden, dan persentase $24,33 \%$ responden tidak dapat menjawab pertanyaan. Dari hasil tersebut menandakan bahwa website e-academic D4 Teknik Informatika dinyatakan baik.

\section{REFERENSI}

[1] Nielson, Jacob, Usability 101: Introduction to usabability, 2011 [Online]. Available: http://useit.com/alertbox/20030825.html/

[2] Krug, Steve, Don't Make Me Think! A Common Sense Approach to Web Usability, New Riders, California, 2006.

[3] Rusidi, Evaluasi Website E-Government Instansi Pemerintah Daerah Kabupaten Ogan Komering Ulu dan Ogan Komering Ulu Timur, 2011.

[4] Arikunto. S, Prosedur Penelitian Suatu Pendekatan Praktik. Edisi Revisi 6, Rineka Cipta, Jakarta, 2009. 